\title{
Quality of Plankton and Physic-chemical Factors to Support Fisheries and Community Care in Babon River, Semarang, Central Java, Indonesia
}

\author{
Jafron Wasiq Hidayat ${ }^{1 *}$, Maryono Maryono ${ }^{1}$, and Rini Budhihastuti ${ }^{1}$ \\ ${ }^{1}$ Study Program of Magister of Environmental Science, Undergraduate School of Diponegoro \\ University Semarang 50162, Indonesia
}

\begin{abstract}
The research was conducted by observing the plankton biota, especially in the interaction and relationship between riverine biota and environmental factors. Plankton enable to provide an indication of environmental changes by determining the diversity $\left(\mathrm{H}^{\prime}\right)$ and evenness (e) indices. Plankton sampling was carried out at 4 stations with different environmental conditions. Plankton were sampled using filtering method and analysed based on their diversity and evenness. Besides, analysis of its saprobic is also carried out to determine the level of pollution. The results showed that the most common species of planktons were Thallasiosera $s p$ and Nitzchia spp. Thallasiosera dominates stagnant waters (dams) and prospect to support the growth of fish larvae. Other species which contribute to feed the fish larvae were Closterium. Diversity Index ( $\left.\mathrm{H}^{\prime}\right)$ shows that the status of the environment stability is in moderate condition, driven by temperature and speed of flow of the water. It is suggested that vegetative conservation on riverside area could reduce the temperature and speed of water flow and so providing more suitable habitat for biota therein
\end{abstract}

\section{Introduction}

Water resources have a significant value and function for life, so their existence must be managed. Rivers have an essential function in providing clean water, shelter for biodiversity, food sources, tourism, and other environmental health $[1,2]$. The river is a habitat for fish, an essential source of food for the community. Many aquatic resources are currently experiencing changes in quality and quantity systematically and only leave a relatively small part of the clean river. Various efforts from the government and community are trying to protect the water body, including exploring its tourist potency [3,4]. However, it did not appear to be balanced with the ongoing disturbances.

In most cases, the problems of rivers and reservoirs are always related to pollution and damage to the watershed area due to changes in land usage [5]. One such river is the Babon river, a clean river program (Prokasih) in Semarang and its tributaries. The upper Babon watershed is part of the Babon Watershed in Semarang City, and Regency covers an area of 6662.52 ha [6]. This river crosses various landscapes and rural settlements on the eastern side

* Correspondent author: wasiqiep@,gmail.com 
of Regency and the City of Semarang. The Babon River is one of the significant contributors to flooding in eastern Semarang $[5,6]$, although, in the dry season, the flow tends to be very small. This dynamic condition threatens the environment and can affect river biodiversity, particularly on the plankton as a primary producer, the bottom chain of the food web $[7,8]$.

In the midland part of the Babon River, the Pucang Gading dam/reservoir was also built, which allowed the nekton to evacuate (migrate) during the dry seasons. However, the existence of reservoirs also acts as a barrier for fish to migration up and downwards. River bodies usually vary in physical and chemical factors that interact with plankton, so they depend on localities. For example, in the inlet rivers of Rawapening lake, Samudra et al. (2013) found 25 species, whereas Haryati and Putro (2019) and Hidayat et al. (2019) found about 25 species $[7,8,9]$. Plankton diversity contributes to the breeding, survivorship, and recruitment of the fish population since most planktons consume natural foods at an early growth stage $[10,11,12]$. The low level of biodiversity, especially fish, reduces the value of social benefits to reduce the sense of belonging and community concern. To achieve river care efforts, it is necessary to conduct an initial study of the biotic structure, i.e., plankton assemblage of the river about environmental and fish feed factors. This study aimed to analyze the stability level of the aquatic environment based on the diversity and abundance of plankton. It is also to analyze the quality of the physical and chemical factors of the aquatic environment based on water quality standards and their interaction to support fishery prospect.

\section{Methods}

This research was conducted from April to November 2020 (end of the dry season) in the Semarang Regency and Semarang City. Laboratory analyses were carried out at the Ecology and Biosystematics Laboratory of the Department of Biology, Faculty of Science and Mathematics, Diponegoro University, Semarang. The research was done by sampling at four stations determined based on the various land usages and conditions around the river bodies, as performed by the author's previous research [7,9]. Sampling locations chosen include the forest-edge area (Dusun Kalikayen, Ungaran), rural settlement (Dusun Kedungsari, Tembalang), Pucang Gading dam (Semarang City), and irrigation drainage (towards Penggaron area Semarang City). The water biota taken into account is plankton which can be analyzed for its population structure to qualify the condition of its environmental stability as done by previous research [7,8]. Environmental stability is also related to physical and chemical environmental factors so that an interaction between the two parameters can be described. Samples of plankton organisms were taken by filtering 301 of water using plankton net number 25 [13]. Measurement of physical and chemical parameters carried out in situ includes $\mathrm{pH}$, current, brightness, turbidity, temperature, and DO. Parameters measured ex-situ included heavy metal $\mathrm{Pb}$, nitrate, phosphate, and organic matter. The procedure is done as carried out by a previous study [14].

Data analysis of plankton was performed using the Shannon-Wiener diversity ( $\mathrm{H}$ '), evenness (e), and dominance indices (Di). Biota diversity is calculated based on the ShannonWiener formula [15]; see Equation 1 and 2.

$$
\begin{aligned}
& H^{\prime}=-\sum_{I=1}^{n} p 1 \ln p 1 \\
& p i=\frac{n i}{N}
\end{aligned}
$$

Where $\mathrm{H}^{\prime}$ is Shannon-Wiener diversity index, ni is $\mathrm{i}$-th species number, and $\mathrm{N}$ is total species.

The Evenness index (e) or species distribution index shows the distribution pattern of a species in a community. If the distribution index is high, it indicates that the species is evenly distributed [16]; the evenness value can be calculated as follow (Equation 3 and 4): 


$$
e=\frac{H^{\prime}}{H \operatorname{maks}}
$$

Hmaks $=\ln S$
(3)

(4)

Where e is evenness value; H': diversity index; Hmaks: Diversity index maximum; S: total species. The saprobic study is used to identify the quality of the aquatic environment using plankton assemblage. The saprobic coefficient determined with the Dresscher and Van Der Mark equations [17], calculated using Equation 5:

$$
X=\frac{C+3 D-B-3 A}{A+B+C+D}
$$

Where $\mathrm{X}$ is the coefficient Saprobic, vary between -3 up to $+3, \mathrm{~A}$ is species number of Cyanophyta group (Polisaprobik), B is species number of Euglenophyta group ( $\alpha$-Mesosaprobik), $\mathrm{C}$ is species number of Chlorophyta group ( $\beta$-Mesosaprobik), D is species number of Chrysophyta group (Oligosaprobik)

\section{Results and Discussion}

The enumeration in plankton population results shows at least 25 species found in the Babon River. In spatial terms, the number of these species varies between 11 and 20 species. This is in line with the research results conducted by Haryati and Putro (2019). They obtained almost the same about 14 to 18 species in the Rawapening Lake, Central Java, with the total number of individuals being between 1,833 to 4,935 individuals per liter. The most abundant plankton was observed in the outlet drainage of Pucang Gading dam (Stat.4) as much as 2006 individual/ 1 . This condition is related to the physical and chemical quality of the drainage waters. The watercolor is shallower, allowing more sunlight exposure, event up to the bottom to support the plankton growth. The least species diversity is observed in the dam body water, which is associated with the slow movement of the current. The stagnant water causes sedimentation (settlement) to support the material degradation process, producing nutrients for phytoplankton bloom [8]. This condition, unfortunately, supports more dominant species to grow but suppresses other species (low in population). Thallasiosira sp is the dominant species, especially in the Pucang Gading dam, which reaches a density of 1683 individuals / 1. Other species that tend to be expected were Closterium sp and Nitzchia spp., with a maximum density of 232 and 136 individuals /1, respectively. Thallasiosira and Closterium are often the dominant species, usually associated with high water nutritional value [18,19]. In other locations ; Nitzschia, Fragilaria, Cymbella, Melosira, Coelastrum Pediastrum, and Eudorina as dominant species in fish pond [20]. These species are the most preferred natural fish food. In goldfish culture, the preferred plankters are Pediastrum and Botryococcus, while the primary feeds for carp larvae on the 15th day are Microspora and Botryococcus [10]. Scenedesmus abundance, Monoraphidium minitum, and Chlorella are also consumed by Tilapia [21]. Blue-green algae like Microcystis and diatoms are the most dominant phytoplankton in the diet of Nile tilapia [11]. The most crucial zooplankton species is Diaphanosoma crustacean which is the most preferred zooplankton by fish $[22,23]$. Whenever plankton is booming, it can be used fish, mainly Tilapia as a grazing agent, which benefits the ecosystem management. The grazing effects of tilapia on microzooplankton were more substantial during the algal bloom [12].

These species reproduce rapidly under favorable nutritional and environmental conditions. High nutrient content in the Pucang Gading reservoir (7.24 mg / lt for nitrate) provides a profitable opportunity for Thallasiosira, Nitzschia, and Closterium. On the other hand, the high plankton density also enables to absorption of more aquatic nutrients, at least providing the benefit of reducing the nitrate content of the water. This can be proved in the nitrate quality on the dam outlet drainage, which has decreased as low as $4.12 \mathrm{mg} / \mathrm{l}$ and increased plankton abundance. 
Table 1. Diversity and abundance (individual / 1) of plankton assemblage in Babon river, Semarang.

\begin{tabular}{|c|c|c|c|c|c|}
\hline No. & Species & St 1 & St 2 & St 3 & St 4 \\
\hline $\mathbf{A}$ & \multicolumn{5}{|l|}{ FITOPLANKTON } \\
\hline $\mathrm{a}$ & Bacillariophyta & & & & \\
\hline 1. & Amphora sp. & 102 & 34 & 17 & 34 \\
\hline 2. & Asterionella sp. & 493 & 17 & 17 & 51 \\
\hline 3. & Aulacoseira sp. & 17 & 17 & 51 & 51 \\
\hline 4. & Chaetoceros sp. & 17 & 0 & 0 & 0 \\
\hline 5. & Coscinodiscus sp. & 0 & 34 & 0 & 0 \\
\hline 6. & Cylotella sp. & 102 & 0 & 0 & 136 \\
\hline 7. & Navicula sp. & 17 & 0 & 17 & 51 \\
\hline 8. & Nitzchia sp. & 136 & 0 & 85 & 32 \\
\hline 9. & Pleurosigma sp. & 34 & 153 & 17 & 51 \\
\hline 10. & Rhizosolenia sp. & 17 & 17 & 17 & 51 \\
\hline 11. & Skeletonema sp. & 68 & 0 & 34 & 51 \\
\hline 12. & Synedra sp. & 34 & 0 & 0 & 34 \\
\hline 13. & Tabellaria sp. & 51 & 0 & 0 & 34 \\
\hline 14. & Thalassiosira sp. & 85 & 51 & 1683 & 170 \\
\hline 15. & Thalassiotrix sp. & 0 & 34 & 0 & 51 \\
\hline b. & Chlorophyta & & & & \\
\hline 16. & Closterium sp. & 238 & 17 & 51 & 85 \\
\hline 17. & Scenedesmus sp. & 34 & 17 & 0 & 102 \\
\hline c. & Cyanophyta & & & & \\
\hline 18. & Oscillatoria sp. & 34 & 0 & 17 & 102 \\
\hline d. & Dinophyta & & & & \\
\hline 19. & Protoperidinium sp. & 0 & 0 & 0 & 34 \\
\hline e & Euglenophyta & & & & \\
\hline 20. & Cryptomonas sp. & 17 & 17 & 0 & 612 \\
\hline f & Euglenophyta & & & & \\
\hline 21. & Phacus sp. & 0 & 0 & 0 & 34 \\
\hline g & Pyrophyta & & & & \\
\hline 22. & Ceratium sp. & 0 & 17 & 0 & 104 \\
\hline B & ZOOPLANKTON & & & & \\
\hline 23. & Copepoda (Larva Crustacea) & 17 & 34 & 0 & 0 \\
\hline 24. & Diaphanosoma spp & 0 & 17 & 0 & 0 \\
\hline 25. & Nauplius & 0 & 17 & 0 & 0 \\
\hline
\end{tabular}




\begin{tabular}{|l|l|c|c|c|c|}
\hline & Total Individual & 1513 & 493 & 2006 & 1870 \\
\hline & Total species & 18 & 15 & 11 & 20 \\
\hline
\end{tabular}

Notes :

Station 1 : Kalikayen village, Ungaran

Station 2 : Kedungsari village, Tembalang.

Station 3 : Pucang Gading dam.

Station 4 : Primary drainage Penggaron

The highest abundance was observed at the dam/ reservoir station, while the smallest was in Kedungsari village. This small value is associated with a fast current velocity $(22.3 \mathrm{~m} / \mathrm{sec})$ so that many water nutrients are carried away. The highest was observed in dam body water since the flow is slow in the reservoir and allows deposition and degradation that fertilizes the plankton grow.

The existence of dominant species, especially Nitzschia Closterium and Scenedesmus is essential to support natural fish food [20,21]. Chlorophyta with the highest population is found at the upstream station, which tends to be shallow and exposed to sunlight. This indicates that the grazing activity is low, and fish do not favor it. Bacillariophyta populations are also essential to support the early larval growth of fish [20,12]. The preferred plankters in an artificial goldfish pool are Pediastrum, Microspora, and Botryococcus [10].

In terms of habitat stability, $\mathrm{H}$ ' index shows that the dam drainage station is the highest ( $\left.H^{\prime}: 2,51\right)$. This is related to the most significant value (relative) in planktonic evenness (0.62), which indicates the least in dominant species. It revealed that biologically this station is the most stable compared to the others. It can also be seen from the physical factors such as DO, current, and temperature values that suit the standard water quality. The lowest $\mathrm{H}^{\prime}$ is found in dam body water $\left(\mathrm{H}^{\prime} ; 0,78\right)$ which is affected by the existence of dominant species and the lowest water current factors. Data of these parameters are shown in Table 2.

Table 2. Indices of diversity, evenness and saprobic of plankton on different locations of Babon river, Semarang.

\begin{tabular}{|c|c|c|c|c|}
\hline Index and status & Station 1 & Station 2 & Station 3 & Station 4 \\
\hline Diversity index (H') & 2,29 & 2,38 & 0,78 & 2,51 \\
\hline Stability State & Moderate & Moderate & Moderate & Moderate \\
\hline Evenness index (e) & 0,55 & 0,72 & 0,2 & 0,62 \\
\hline Evenness State & Moderate & High & low & high \\
\hline Saprobic index (X) & 2,17 & 2,27 & 2,27 & 2,00 \\
\hline Saprobic State & Oligo saprobic & Oligo saprobic & Oligo saprobic & $\begin{array}{c}\text { Oligo/ } \beta \text {-Meso } \\
\text { saprobic }\end{array}$ \\
\hline Pollution State & Very light & Very light & Very light & Very light \\
\hline Pollution materials & $\begin{array}{c}\text { Small material } \\
\text { organic dan } \\
\text { anorganic }\end{array}$ & $\begin{array}{c}\text { Small material } \\
\text { organic dan } \\
\text { anorganic }\end{array}$ & $\begin{array}{c}\text { Small material } \\
\text { organic dan } \\
\text { anorganic }\end{array}$ & $\begin{array}{c}\text { Small material } \\
\text { organic dan } \\
\text { anorganic }\end{array}$ \\
\hline
\end{tabular}

Notes :

Station 1 : Kalikayen village, Ungaran

Station 2 : Kedungsari village, Tembalang

Station 3 : Pucang Gading dam.

Station 4 : Primary drainage Penggaron

The result from the calculation of the saprobic index shows a value between 2.00 to 2,27, which indicates very light pollution $[7,24]$. The material contributing to the above matter is 
organic and inorganic materials in small numbers, likely coming from land farming practice. The quality of the physical factor is most suitable, but BOD is not suitable [2]. Such a low pollution status offers good prospects to develop fish release action (wild release method) to enrich the diversity or even culture practice. These actions were beneficial to support public awareness, especially to promote river care community based on fish attraction.

Meanwhile, the value of nitrate varies between $3.14-7.24 \mathrm{mg} / 1$, which is still below the water quality standard for Class II for cultivation $(10 \mathrm{mg} / 1)$. The highest value is measured upstream of the Babon river. It receives runoff from its vast fertile forest of Penggaron as a catchment area and domestic waste from Ungaran city. The nitrate tends to be low until it reaches Kedungsari Station because the village area is generally applied dryland farming. There is not much domestic drainage in the area connected to the river. Most of the domestic waste is stuck in household drains and house yards. Besides, fast-moving water here also reduces the mineralization process. Nitrate content increases in reservoirs $(7,24 \mathrm{mg} / \mathrm{l})$ are associated with accumulated sludge with a high organic material content $(2,83 \mathrm{mg} / \mathrm{l})$. Figure 1 draws the concentration of nitrate, phosphate, $\mathrm{Pb}$, and organic content on a different station. The water flow in the dam is measured to move $0 \mathrm{~m} / \mathrm{sec}$, so the transported material along the river will be deposited and become the subject of the degradation process. This will cause plankton to grow densely and, as a matter of effect, reduce sunlight penetration. As a result, there will be many planktons trapped to death or hibernate in the middle and lower layers due to limited sunlight, thus increasing the organic content of the waters.

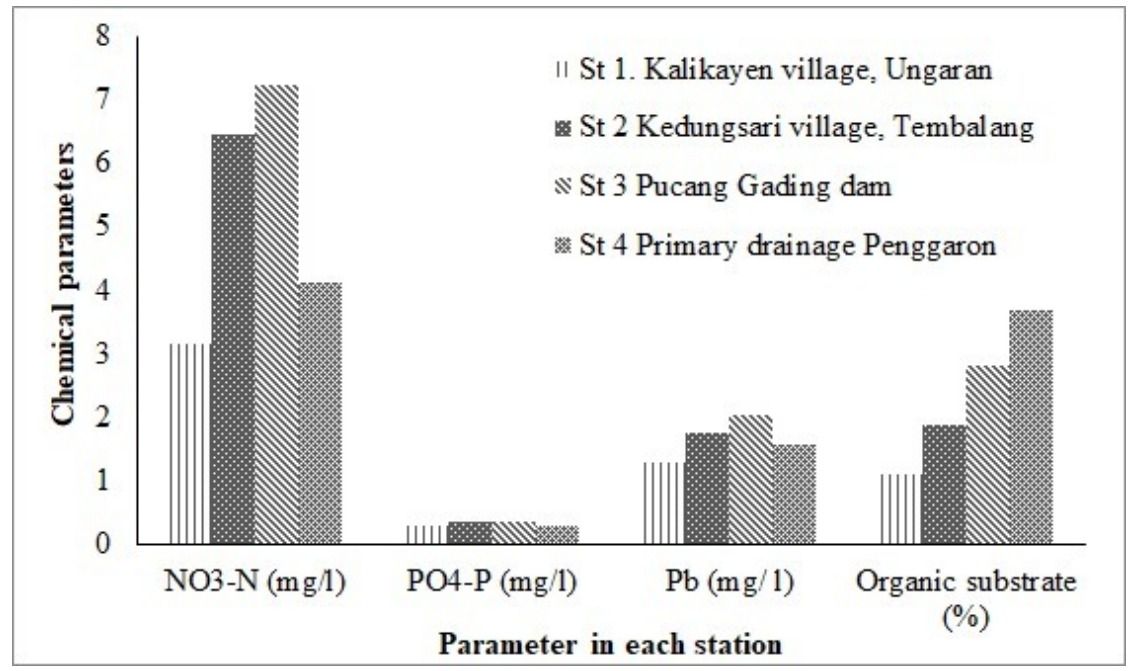

Fig. 1. Chemical parameters in different station of Babon river, Semarang.

Muddy substrates are associated with accumulated metal contaminants, including $\mathrm{Pb}$ as high as $2,02 \mathrm{mg} / \mathrm{l}$. The water flow in the dam can be said to be $0 \mathrm{~m} / \mathrm{sec}$ in moving, so the transported material will be deposited and become mud accumulation. Mud material can entrap the $\mathrm{Pb}$ molecule through an adsorption mechanism [13]. This will potentially be transported to herbivore/ plankton, mainly fish, through a bio-absorption mechanism [25]. 


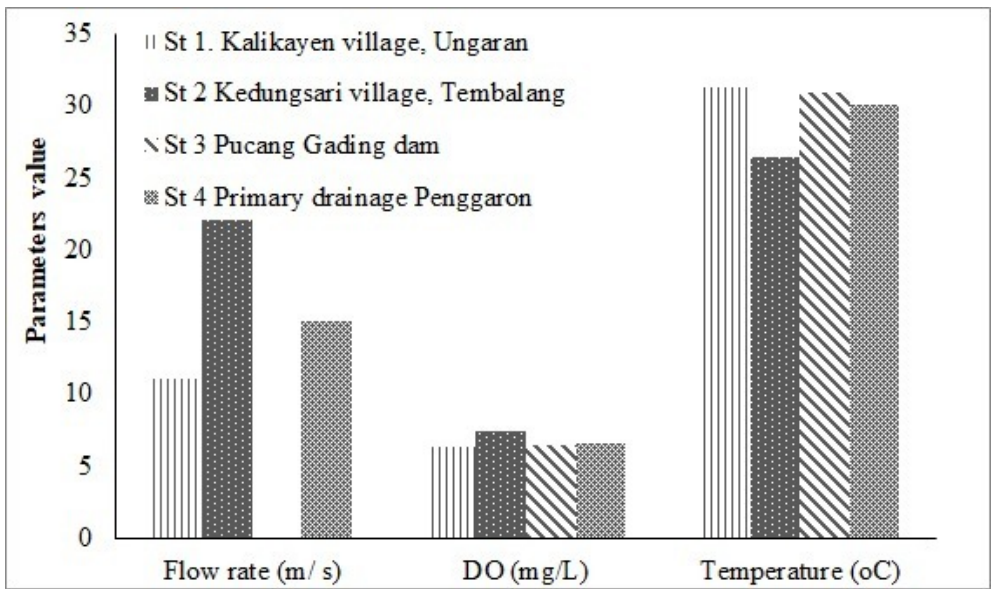

Fig. 2. Physical factor in several station of Babon River, Semarang.

The water temperature shows that the lowest temperature is measured in Kedungsari village, where this location is still found in a pool of water bodies and dense riverside vegetation. Fish schools prefer pool body water since the ambient temperature is more stable, especially when the water recedes decrease in current, especially when there is flow/ circulation so that mud accumulation does not occur. In contrast to the dam area, although the temperature is consistently low $\left(30.90^{\circ} \mathrm{C}\right)$, the water is stagnant so that the flow/ circulation is none. This causes the accumulation of dissolved particulate material, which usually creates a muddy substrate of organic material. High sludge triggers a high demand for oxygen to break down organic material (BOD), which spends more in oxygen stock and therefore consumes more oxygen and decreases DO value, especially during the night. Low oxygen below three ppm significantly inhibits the respiration of various fish [26,27].

Flow rate is also an essential factor to the plankton abundance, where the fastest flow was measured in Kedungsari village, and the lowest was in Dam. The plankton abundance in Kedungsari was the lowest (493 individual/ 1), whereas in Pucang Gading dam was high as 2006 individual. 1. Figure 3 illustrates the trend where the faster the current, the lower the abundance of the plankton. Fast water current will drain the organic material of the water and reduce the degradation to produce minerals for the growth of plankton. As the water reaches midland and lowland, the current will be slower, even static in the Dam, allowing light material to settle as organic mud. This became the subject of degradation, affecting water nutrition and plankton abundance [7]. This can be found in dam water where the current is the lowest, highest in nutrition (highest nitrate concentration), and highest plankton abundance. The high trend nitrate here is consistent with previous research [28]. 


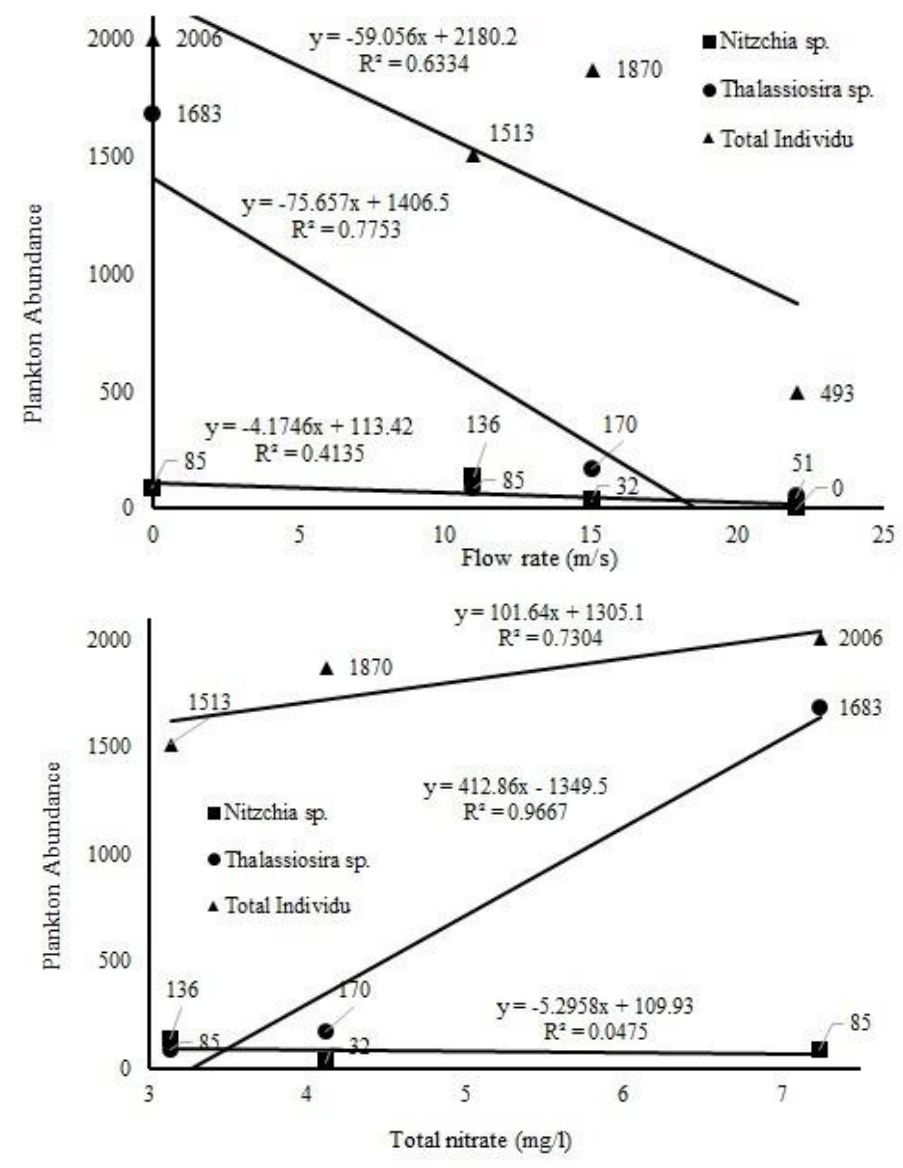

Fig. 3. The relationship between plankton to water flow (upper) and nitrate value (below).

The highest temperature is measured in Kalikayen village, upstream, due to the shallow water body water (ripple body water). The current velocity is also low $(10 \mathrm{~m} / \mathrm{s})$, so that it has the potential to be exposed to sunlight and become much warmer during the day. Such water is less preferred by biota and can be proved by the least of plankton assemblage. Figure 3 illustrates that the faster the water flow, the lower the abundance of the plankton. High water temperature causes an effective respiration rate, making it unsuitable for biota, especially fish. Efforts to manage the fish problem can be made by creating artificial 'fish apartments' made of stone or other solid material for physical protection to the fish. Another technique is to create an artificial puddle pool in a river body. There are many boulder stones in Rowosari which are adequate to build the artificial structure. It is also essential to do replantation in the riverbank. This will increase the shade and keep the infiltration water more significant to produce clean and cool water. Riverside communities usually also grow many plants at the edges and conserve the land on the banks of river embankments.

\section{Conclusion}

There were at least 25 species of plankton found, with the most commonly observed being Thalassiosira sp, Nitzschia, and Closterium sp. Based on environmental factors, it shows that the status of the waters has decreased along with the more complex usage of rivers. 
However, in general, the level of balance/stability shows a medium condition. The contamination condition is still very light, while the potential for wild fisheries is still a prospect, especially in reservoir bodies. In shallow waters, the most significant environmental constraint is the relatively high water temperature during the day, so it is necessary to reduce by re-vegetation method along the riverside and develop fish apartments for fish refugia.

\section{Acknowledgements}

Thanks are addressed to Diponegoro University for funding this research base on the research contract no 449/UN 7.P/HK/ 2020 date May the 13th year 2020. Thank is also directed to Febiani Dwi Utari and Zulhaq D Siqhny to prepare this script

\section{References}

1. Government Regulation, No 82, year 2011, Water quality management and water pollution control, Jakarta (2011)

2. M.N. Suparjo, Saintek Perikanan: Indonesian Journal of Fisheries Science and Technology 4, 2 (2011)

3. Kusaeri, P.P. Sapto, W.H. Jafron, Journal Biology and Biology Education 7, 2 (2015)

4. S. Ifandi, Y.A. Rahma, Biosaintifika : Journal Biology and Biology Education 12, 3 (2020)

5. Setiawan O. and M P. Hadi, http://etd.ugm.ac.id/index.php?mod=penelitian _deta...Authors (2008)

6. Oktarina D., Analisis Spasial Perubahan Penggunaan Lahan Di Das Babon Hulu Terhadap Debit Puncak Sungai Babon Jawa Tengah. Under Graduates thesis, Universitas Negeri Semarang (2016).

7. J.W, Hidayat, R.B. Hastuti, M. Hadi, G. Yulianto. Journal of Physics. Conf. Series 1217 (2019)

8. R. Hariyati, S. P. Putro. Journal of Physics: Conference Series Conference Series, 1217 (2019)

9. Samudra, SR; TR Soeprobowati, dan M Izzati, Bioma, 2013 - eprints.undip.ac.id (2013)

10. A.A. Widiana, K. Kusumorini, S. Handayani, Al-Kauniyah Jurnal Biologi 6, 2 (2013)

11. A. Tesfahun, M. Temesgen, International Journal of Fisheries and Aquatic Studies; 6, 1 (2018)

12. F.R. Vasconselos, R.F. Menzes, J.L. Attayde, Hydrobiologia 817 (2018)

13. J.F. Hidayat, R. Hariyati, S,P. Putro, Advanced Science Letters 23, 7 (2017)

14. Ekubo, A. A., \& J. F. N. Abowei., Research Journal of Applied Sciences, Engineering Technology, 3(12), 1342-1357. Retrieved from http://maxwellsci.com/(2011).

15. Magurran, A. E. Ecological Diversity and Its Measurement. Chapman and Hall: USA. (1988)

16. Odum E.P, Dasar-dasar Ekologi (terjemahan). Edisi ke-3. Gadjah Mada University Press. Yogyakarta. (1998)

17. Dresscher \& van der Mark. Journal Hydrobiologia, 48(3), 199-201. (1976)

18. Hariyati R., W. Wiryani, Y.K. Astuti, Bioma 11, 2 (2009) 
19. Soeprobowati TR., J. Hidayat, and K. Baskoro, Jurnal Sains Dan Matematika, vol. 19, no. 4, pp. 107-118, Jan. 2015

20. Pratiwi N.T.M., Y.H.E.Winarlin, A. Frandy, I. Iswantari, Jurnal Akuakultur Indonesia 10, 1 (2011)

21. Oya-Işik A., E.Sarihana, E. Kuşvuranb, O. Gülb, O. Erbaturb, Aquaculture 174, 3-4 (1999)

22. Alexander V. Zale and Richard W. Gregory, Vol. 53, No. 2, pp. 123-129 (7 pages) (1990).

23. Pratiwi, NTM, Winarlin, YHE Frandy, A. Iswantari, Jurnal Akuakultur Indonesia 10 (1), 81-88 (2011)

24. Basmi, J., Fakultas Perikanan dan Ilmu Kelautan. Institut Pertanian Bogor. Bogor (2000)

25. T.R. Soeprobowati, R. Hariyati, American Journal of BioScience 2, 4 (2014)

26. Soeprobowati, T.R Mitigasi Danau Eutrofik: Studi Kasus Danau Rawa Pening. In Prosiding Seminar Nasional Limnologi VI Semarang (2012)

27. Suparjo M.N., Kajian Potensi Kegiatan Sumberdaya Perikanan Rawapening Kabupaten Semarang (Study off Potential For Fisheries Resources Activity Rawapening) Program Studi Manajemen Sumberdaya Perairan, Jurusan Perikanan, Fakultas Perikanan dan Ilmu Kelautan, Universitas Diponegoro (2017)

28. Piranti A.S., D.R.U.S. Rahayu, G. Waluyo, Indonesia; Biosaintifika Journal of Biology \& Biology Education 10, 1 (2018) 